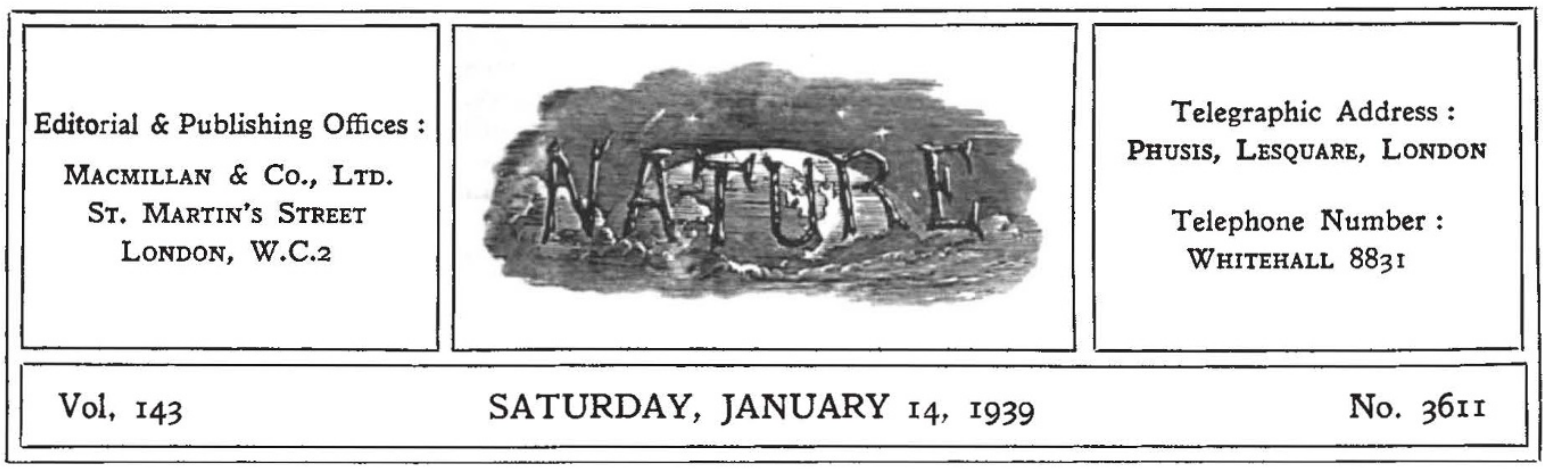

\title{
Intellectual Co-operation between the Nations
}

W live and move and have our being in a has shrunk in its dimensions to an almost incredible extent during the last generation. America and the Antipodes are but a few days' journey from Europe; wireless can put a girdle round the globe in a time undreamt of by Puck; the concerted labours of the physicist, the engineer, and the biologist have made it possible to transport perishable produce on a large scale from country to country-produce which adds in a high degree to the amenities of life in our community. All these results have been achieved by thought and labour which were truly international in character.

The fundamental problems of life, of art and of ordered knowledge know neither racial nor geographical boundaries. Grant that we have reached a certain stage in our gropings into the infinite, then, within those limits, the message of Plato and of Confucius, of Dante and of Wordsworth, of Beethoven and of Brahms, of Newton and of Einstein, are for all ages and all climes. Unless man is free in thought, and free in the expression of his thoughts, the wisdom of the past and of the present is of small avail for the increase of the happiness of the human race; and it is a bitter comment on the trend of our modern civilization that men should be turning to the noble words of the Areopagitica as expressing beliefs still to be fought for, not as truths for ever demonstrated by the struggles and aspirations of centuries past and gone.

"As good almost kill a man as kill a good book ; who kills a man kills a reasonable creature, God's image; but he who destroys a good book, kills reason itself, kills the image of God, as it were, in the eye. . . . We should be wary, therefore, what persecution we raise against the living labours of public men, how we spill that seasoned life of man, preserved and stored up in books; since we see a kind of homicide may be thus committed, sometimes a martyrdom ; and if it extend to the whole impression, a kind of massacre, whereof the execution ends not in the slaying of an elemental life, but strikes at the ethereal and fifth essence, the breath of reason itself; slays an immortality rather than a life." How would these immortal words have struck our ears in the freer air of a generation ago ? How do they read to-day?

We have said that we live in a world of contradictions, for, though the gifts of science have brought the nations closer in space and in time than ever before in the history of civilization, yet, paradoxically enough, man stultifies the effects of these benefits in countless ways. $\mathrm{He}$ erects economic barriers between the nations; he exacerbates national disagreements, visualizing the exchange of commodities, on which our mutual prosperity depends, as a process of warfare; he produces want and misery in a world which, wisely ordered, could go far in using the gifts which scientific advance is providing, to supply the material needs of all.

All the more reason, then, to welcome any national pronouncement which emphasizes the spirit of co-operation rather than that of cutthroat competition, and such a pronouncement is doubly welcome when it is concerned with the fostering of general cultural relations between a great democracy and the other countries of the 
world. The order recently signed by Mr. Cordell Hull, the Secretary of State in President Roosevelt's Government, establishing in the Department of State a Division of Cultural Relations, is of great significance. In a civilization where knowledge is increasing, where values are changing, at a rate never before dreamt of, and in which almost every possible element of instability is present, no opportunity should be lost for bringing together nationals of all countries to discuss, amicably and fraternally, problems which are the concern of all, and few better meeting grounds could be chosen than those which are provided for the encouragement and strengthening of cultural relations. Individual attempts to institute such contacts have been many and have been attended with varying degrees of success, or failure, but Governments are slow to take such action, and Mr. Cordell Hull's order marks an important step in advance, and provides an example that may well be followed by other Governments as a most weighty means of diminishing the tensions, and alleviating those differences which, unhappily, are such a prominent feature in international relations to-day. The order, which takes effect as from July 1938, has scarcely, as yet, received the notice which its importance merits. The significant part of the text, as published in the issue of Science of November 25, 1938, runs :

For the purpose of encouraging and strengthening cultural relations and intellectual co-operation between the United States and other countries, it is hereby ordered that there shall be established in the Department of State a Division of Cultural Relations.

The division will have general charge of official international activities of this department with respect to cultural relations, embracing the exchange of professors, teachers and students ; co-operation in the field of music, art, literature and other intellectual and cultural attainments; the formulation and distribution of libraries of representative works of the United States and suitable translations thereof; the preparations for and management of the participation by this government in international expositions in this field; supervision of participation by this government in international radio broadcasts; encouragement of a closer relationship between unofficial organizations of this and of foreign governments engaged in cultural and intellectual activities, and, generally, the dissemination abroad of the representative intellectual and cultural works of the United States and the improvement and broadening of the scope of our eultural relations with other countries.

In fulfilling its functions, the Division of Cultural Relations will direct the conduct of exhaustive studies and have responsibility for the elaboration and the carrying into effect of a comprehensive and co-ordinated plan of activity in this country for the strengthening of international intellectual and cultural relations; it will assist in the preparation and interpretation of treaties in this field; it will supervise the formulation of regulations and procedure necessary for the fulfilment of obligations under the Convention for the Promotion of Inter-American Cultural Relations and other treaties and conventions relating to cultural relations to which the United States may become a party; it will draft or review correspondence with foreign governments, American diplomatic and consular officers and all other correspondence pertaining to these activities; it will collaborate with the Office of Education and other government departments and agencies, the National Committee on Inter-American Intellectual Cooperation, other educational and cultural organizations and institutions and foreign missions in Washington.

The Division of Cultural Relations will function under the general supervision of the Under Secretary of State and in close co-operation with the geographical divisions.

It will be noted that science receives no overt mention, but it is to be presumed that scientific advances and the implications of such advances will receive full consideration under some of the more general heads of the order.

Official action in democratic communities is apt to follow, rather than to lead public opinion, save in exceptional instances, but Mr. Cordell Hull's order synchronizes with other movements which have already been discussed in the columns of Nature. The British and American Associations for the Advancement of Science, in their arrangements for an exchange, in alternate years, of lecturers to deliver at the meetings of the Associations addresses which shall, broadly speaking, be conceived on the lines of presidential addresses, have initiated a movement which will undoubtedly have far-reaching effects ; and this movement is further assisted by the decision of the Associations to keep officials of each Association intimately acquainted with the details of the proceedings of their respective bodies. It is good to know that the Government of the United States of America regards these decisions as having sufficient importance to warrant their forming part of a wider national policy, and such recognition inspires the hope that other countries will participate in this movement for the encouragement of international cultural relations.

The structure of our civilization is cracking; if it is to be saved at all-and, imperfect though it may be, it is worth conserving and developingit can only be saved by the encouragement of those movements which stress the urgent need for international co-operation and understanding. 